\title{
RURAL LANDSCAPES IN LATVIA: A COMPARATIVE ANALYSIS OF REPRESENTATIONS AND PERCEPTIONS
}

\section{Lauku ainavas Latvijā: atainojuma un uztveres salīdzinošā analīze}

\author{
Andris Klepers, Iveta Druva-Druvaskalne \\ Vidzeme University of Applied Sciences, Institute of Social, Economic and \\ Humanities Research \\ e-mail: andris.klepers@va.lv
}

\begin{abstract}
As a reflection of Latvian identity, the country's rural landscapes are a living embodiment of both natural and cultural heritage, contributing to quality of life for local communities and serving as a magnetic pulling factor for international tourists. Traditional farmsteads (viensētas) are perceived as symbolic spaces which have developed gradually, especially since the 19th Century, through annual cycles of farm work alongside extensive farming. Yet their existence is threatened by the impact of transitional changes such as depopulation, globalisation, the non-competitive nature of traditional farming models, and changes in society and the lifestyle of young people. Many abandoned farmsteads are disappearing under large areas of cropland or forest, and some newly built private houses do not have a connection with the traditional rural landscape. The aim of this study is to explore the way that perceptions of farmsteads and rural landscapes have changed over time within local communities. This is done by comparing representations of countryside landscape ideals in the media from 1920 to 1940 and perceptions of farmsteads as an element of countryside landscapes within local rural communities today ( $<12 \%$ of the population of Latvia lived on a farmstead in 2019). The findings show that in the period when most people lived in the countryside, a particular kind of idealised rural landscape was often visually represented in the mainstream media, strengthening stereotypes about symbolic landscapes. These concepts are still strongly rooted in the perceptions of current rural inhabitants and there was consensus among respondents about the elements which are associated with high-quality rural landscapes. Although the daily routines of the traditional farmstead today have been changed by a number of factors and many elements of the rural landscape have lost their functionality, symbolism including the iconic image of separate family farmsteads - helps to maintain a continuing metanarrative of national identity, creating nostalgic ties which lead many to have a preference for living in the countryside, holding perceptions about the availability of various ecosystem services next door which will improve their quality of life.
\end{abstract}

Keywords: rural landscape, farmstead, perception, identity

DOI: $10.22364 / \mathrm{fg} .18 .10$

\section{Introduction}

Due to its symbolic significance to the national identity (e.g. Bunkše 1999; Zigmunde 2010; Dzenovska and Aistara 2014), the farmstead of the $16^{\text {th }}-21^{\text {st }}$ century is included in the Latvian Culture Canon. This is an acknowledgement of its great value "reflecting significant cultural achievements of the nation that should be learnt, preserved and developed creatively to serve the demands of future society" (Culture 
Canon 2018) and pays attention specifically to its significance to national identity at the time of the 100th anniversary of the Republic of Latvia. This is not only because of its architectural value (Ozola 2015), but because of the value of the landscape as a whole: "as spatial formation shaping uninterrupted surface - the pattern depending both on environmental circumstances and on territorial features of people's activities" (Melluma 2012). At the same time, farmsteads are considered to be biodiversity hotspots which are often overlooked (Hiron et al. 2013; Rosin et al. 2016), although land abandonment caused by rural depopulation has significant ecological consequences. The disappearance of a fine-grained mosaic-like landscapes leads to their simplification, homogenisation and the loss of many semi-natural habitats, resulting in a reduction of biodiversity (Henle et al. 2008; Ruskule et.al. 2013). The findings of research with regards to contemporary attitudes towards nature show that they frequently differ from practical reality (Bunkše 1978). The transition of farmsteads from rural places where particular farming practices are carried out to modern dwellings with various inherited landscape elements (created for practical or aesthetical reasons) is not always coherent. Rural areas can be perceived as "something to which people belong, as to a commonwealth, a land is constituted by the people that belong to the land insofar as they have become attached or bound [to it] ... by birth, allegiance, residence, or dependency" (Olwig 2012) or "as a particular spatiality in which a geographical area and its material appearance are constituted through social and environmental practise" (Cosgrove 2006). A farmstead forms a holistic representation of the countryside for all the "outsiders" (e.g. urban people, tourists), who would like to experience it: for example, in northern Sweden, the provision of accommodation on farms and typical landscape settings are considered to be important factors for attracting tourists (Gössling and Mattsson 2002). Farm-based tourism has long traditions, in many countries dating back over a century (Dernoi 1983; Sharpley and Vass 2006), and according to Walford (2001) is the most common form of tourism on farms located in or near scenic areas. Rural landscapes contribute to additional value of the tourism services in situ with scenic views, also make roadsides of the transit routes towards the tourism destinations more attractive (Vugule 2013) forming designated "landscape roads" (Vugule and Turlaja 2016).

The Latvian rural landscape has been shaped by many fracture points caused by humans in the last century (see Figure 1). The impact of economic, social and political factors on the rural landscape structure and its changes has been extensively analysed in Latvia, especially by Nikodemus et al. (2005; 2010) and Bell et al. (2009), and specific aspects have been studied by Penēze (2009), Aistara (2009), Vanwambeke et al. (2012), Ruskule (2013), Vinogradovs et al. (2018) and others. Using the theory of path dependency in her research about the rural landscape, Zarina (2010) summarises the main causes of landscape evolution comprehensively outlined in Melluma's (2012) history of the development of the Latvian landscape. 


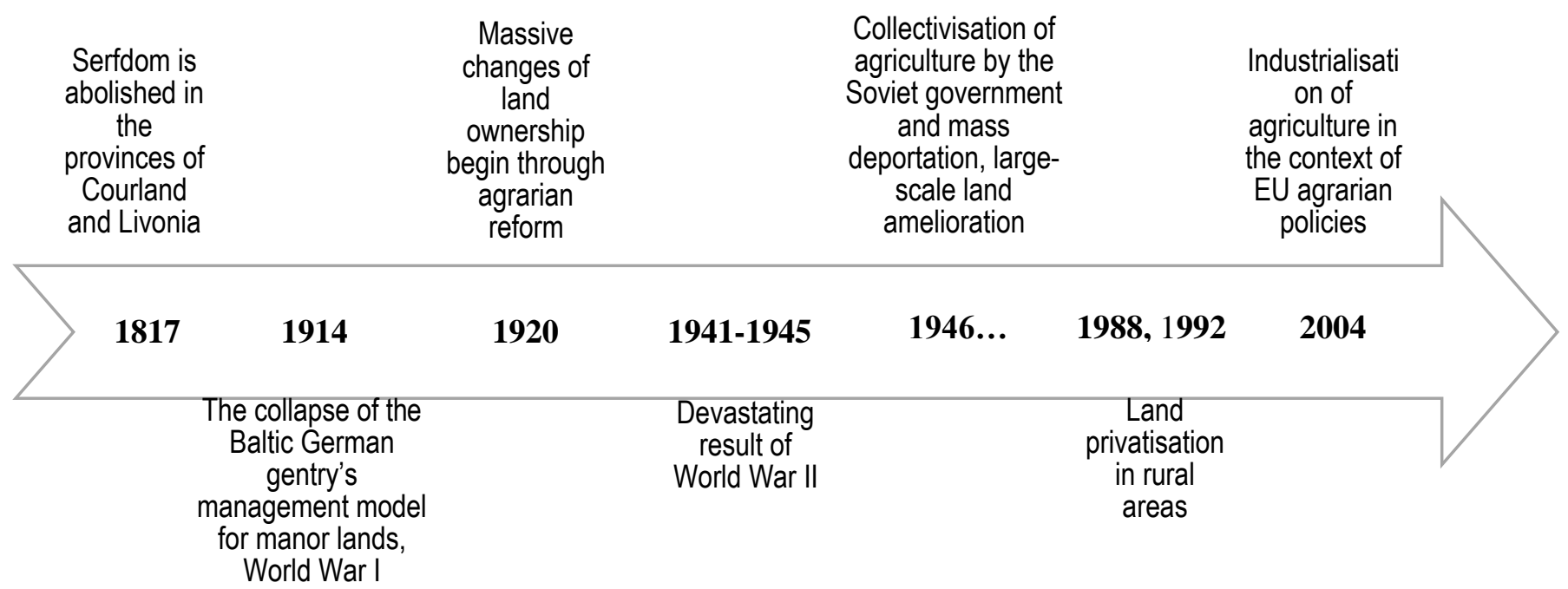

Figure 1. Main fracture points of the Latvian rural landscape in the context of farmstead development (authors' figure)

The rural landscape has changed not only in the context of tangible land-use practices, but also in terms of its representation and the way it is perceived. Nature and culture cannot be completely separated, and landscapes reflects the shifting boundaries between them. In a wider sense, the common heritage of the local rural farmsteads has had significant contribution both - for the lifestyle of local communities, but also created specific niche habitats for many other species. It could be said that the fate of the rural farmstead is now a global issue, due to international conventions on landscape, biological diversity and the protection of world cultural and natural heritage. The rural landscapes of today differ due to their dynamics in terms of space, time and scale, as well as people's changing views, values and behaviour (Antrop 2005). Although large stretches of rural landscapes have been modified and adjusted to meet the needs of today's societies (Xu et al.2009), elements of the historical usage of farmsteads can almost always be seen in the natural environment in and around them. This could be a lone large tree, giving the sense of a crossroad, or a birch alley, reminding us of the beekeepers that inhabited the area (Zarina 2010). Recent research on landscape aesthetics and the value of natural diversity done by French researchers highlight the conceptual background, current methodologies, and future challenges of assessing landscape aesthetics and its relationship with nature (Tribot et al. 2018). Humans' aesthetic perception of the rural landscape is a complex behaviour in which cultural background plays a central role. To understand this comprehensively, a combination of sociology, psychology, neurology and ecology is required. 


\section{Methods}

A comparative analysis of representations and perceptions of rural landscapes in roughly the last century has been examined in this research. For historical data analysis, periodicals from 1920-1940 were used for a textual and visual analysis of the rural landscape, including photographs. To compare perceptions, a survey of rural inhabitants was conducted, with 316 surveys and 72 semi-structured interviews completed. In addition to research using the work of other authors, the following research questions were determined as being the thematic focus of this research:

1) how were rural landscape ideals (and elements connected to the quality of rural landscape represented in the media a century ago (1920-1940) during the formation of the newly independent state and nation?

2) how does modern rural society perceive rural landscapes and what value is attributed to rural landscapes and farmsteads?

The research comprises several successive stages. First, identifying the representative elements of the Latvian rural landscape during the 1920s and 1930s (the qualitative research method used was visual content and photography analysis). The so-called "repetition method" was mostly used ("repeat photography" is a method in visual anthropology) to compare photographs of a specific area during different time periods. The landscape is recognised as an element in social processes (Hirsh 1995; Smith 2007; Metcalfe 2016). This research was based on work by Bell (2001) and Rose (2016), which claim that visual analyses focused on both the contents of the visual material as well as the expression can be used. During visual content analysis, the researcher counts and analyses how often specific visual elements figure in certain images (Rose 2016). For the purpose of this study, we chose to group and count the frequency of landscape-forming elements visible in the photos: for example, forests, water bodies, dunes, large trees, meadows, pastures, cornfields, elements installed around the farmsteads: roads, wooden fences, wells, bee hives, stork nests, bird cages, electrical poles etc. Next, photographs from Atpüta, the most popular weekly paper (842 editions) during the period 1920-1940 were used as a source (obtained using the digital periodical archive of the National Library of Latvia: http://periodika.lndb.lv). The weekly paper had a wide range of readers and circulation increased from 6,000 in the mid-1920s to 70,000 by the end of the 1930s. It was informative and rich in photographic content, despite being the cheapest and most popular weekly publication of the time, serving as an influence on lifestyles among Latvian society. Simultaneously, a textual analysis was conducted on publications of the same time period (Zeltene, Ilustrēts žurnāls, Latvijas jaunatne, Latvijas tūrists, Daba, Magazina, Séjējs, Rìts and Dzimtenes atskaņas). Keywords were searched for in articles: "landscape", "view”, “farm", "fields", “cultivated”, “well-kept”, “typical”, "farmstead", "new farm", "old farm", "homeland" and "farmyard". Thirdly, to understand current perceptions of landscapes, primary data was obtained by surveying local community members. This was done mainly using preference judgment variables tested in the research of Sevenant and Antrop (2009). A semantic differential scale 
with six rating options was used to assess where participants fell on a continuum of various landscape attributes. Although it is difficult to offer clear polar-opposites in terms of representations of landscape perception (e.g. should farmyards be calm or active), in practice participants were easily able to choose from the options given.

The respondent sample $(n=316)$ included owners of farmsteads located in all 110 rural municipalities and locations outside the densely populated areas of Latvia. Most respondents $(n=162)$ lived on their property, the rest managed the land without direct ownership or visited their property only during the summer. Property rights to manage land were mostly inherited from ancestors $(n=144)$ or obtained after 1991 $(n=133)$ by buying the property. In 75 cases, the surveyed farmsteads were in protected natural areas. Gender balance was almost equal, and the respondents ranged in age from 18 to 89 , with the largest number being in the group 41-50 ( $n=87)$. The majority of respondents worked in the private sector $(n=136)$, fewer in the public sector. Out of the 316 surveyed farmsteads, 72 were visited for semi-structured interviews carried out on the spot and a visual inventory of the landscape elements found there. Additional desk research was carried out using the available historical cartographic material. To ensure that the sample was representative, various criteria were applied, including selection of different locations, lifestyle of the owner, employment, main source of income for the household, period of the farmstead's origin, population density and regularity of stay (which in turn affects the priorities and spatial relationships of the landscape elements which have been saved and maintained).

\section{Results}

\section{Representations of the rural landscape: 1920-1940}

The analyses of images of the Latvian countryside reproduced in the publication Atpüta during the period shortly after the creation of the independent Republic of Latvia (see Table 1) demonstrated ideas prevalent within society of "what constitutes a pleasant rural landscape" (or what doesn't) and revealed a consensus that rural life was more valuable than urban life. Stand-alone trees, large trees, forest, meadows, pastures, cereal fields, crops tied in bundles and linen are important landscape elements of the historical landscapes represented there. Elements of farmsteads are visible in historical photographs: wooden fences and horse silage, wells, bird cages, fishing gear, electricity poles, stork nests, beehives and wild animals. Road and small paths were photographed as linear landscape elements. 
Table 1. Representation of landscape-forming elements contained in photographs in the magazine Atpüta (1920-1940)

( $n=842$ issues with 454 photos analysed)

\begin{tabular}{lc}
\hline $\begin{array}{l}\text { Landscape elements } \\
\text { represented }\end{array}$ & $\begin{array}{l}\text { Proportion from } \\
\text { all photos } \\
\text { presented (\%) }\end{array}$ \\
\hline stand-alone trees & 69.4 \\
\hline incl. large trees & 1.8 \\
\hline forest & 42.7 \\
\hline meadow & 27.8 \\
\hline cereal fields & 9.9 \\
\hline animals (livestock, pets) & 4.8 \\
\hline pasture & 3.7 \\
\hline Elements of the farmyards & $\%$ \\
\hline road & 14.8 \\
\hline wooden yard & 8.1 \\
\hline electric poles & 7.0 \\
\hline small paths & 6.2 \\
\hline fishing gear (pots, nets) & 3.7 \\
\hline water well & 0.9 \\
\hline bird nest box or stork nest & 0.7 \\
\hline beehive & 0.2 \\
\hline$-9-0$ \\
\hline
\end{tabular}

The aesthetic taste of rural society was repeatedly influenced by presenting the best maintained farms as benchmark examples. This corresponds to the results of analyses done on regional newspaper discourse in the same period (Lipša 2011). There was also a clear political aspect (as two-thirds of all inhabitants with voting rights lived in the countryside by that time). Of all the regions, the most popular countryside landscapes in photographs were from Vidzeme (56\%) and Kurzeme (16\%). The Daugava river valley $(10.8 \%)$, including 160 different places, was reproduced most frequently, followed by the Gauja river valley and the uplands of Vidzeme. From the analysis of media discourse there was no confirmation that ideas about nature conservation were important factors in decision-making processes regarding the land management of farmyards. The dominant factors were issues of practical management in combination with aesthetic considerations, respect for the ancestral landscape heritage, a desire to demonstrate the status of a wealthy landowner and fear of being perceived as a bad landowner by others.

\section{Perception of the modern rural landscape}

Rural society has common and persistent perceptions of what constitutes rural landscape characteristics although several generations have passed since the pre-war 
period. Common elements of such landscapes are open gaze perspective with pronounced geomorphological formations (e.g. hills), nearness of bodies of water, big old trees, traditional farmsteads housing, patches of forest and winding roads. It is diverse, rich, varied, intriguing, emotionally moving and engaging, rather than predictable, monotonous, uniform and symmetrical. Recent trends in development in the Latvian countryside prove that although most rural commercial accommodation is located near water bodies with scenic views, and self-catering rural holiday homes for tourists are increasingly available, the number of farms which offer countryside lifestyle experiences and accommodation is decreasing (147 are left, down from several hundred 20 years ago). Stereotypical perceptions were reproduced in the survey of countryside landowners almost a century later - the symbolic countryside landscapes seen as being the highest quality are: the Gauja National Park ( $n=99)$, the seaside $(n=71)$, the Vidzeme uplands and the Daugava river valley.

Understanding how farmstead owners think about their farmyard landscape and what influences the process of creative place-making, will facilitates dialogue about taking pro-active measures towards the maintenance of nature or culture heritage. The terms "rural", "backyard" or "outdoors" are often used by landowners and express a sense of local space in contrast to the urban environment. Local space has been enriched with narratives about ancestors, lifestyles, work routines and identity. Space is perceived as possessing a place-making power, where certain images and shapes can be created through the landowner's personal knowledge, understanding, attitudes and decisions. These microcosms are visible to the public gaze and are perceived as either typical or atypical rural landscapes. From the landowners' point of view, farmyards are dynamic spaces where culture and landscape heritage from the past co-exists with new design elements according to the needs of contemporary lifestyles. Compared to the city, they can more easily create an ideal space in a rural area (see Table No. 2), where there is harmony between nature and human needs. This is seen as one of the advantages of permanent residence in the countryside.

Table 2. Summarised perceptions (by the number of respondents) expressed by

landowners regarding the character of the rural landscape in Latvian farmyards $(n=316)$

\begin{tabular}{|r|r|r|r|r|r|r|l|}
\hline Character feature & $\mathbf{1}$ & $\mathbf{2}$ & $\mathbf{3}$ & $\mathbf{4}$ & $\mathbf{5}$ & $\mathbf{6}$ & Character feature \\
\hline rational & 5 & 27 & 55 & 98 & 67 & 60 & romantic \\
\hline practical & 36 & 78 & 93 & 67 & 27 & 12 & aesthetic \\
\hline with extensive garden & 101 & 68 & 78 & 42 & 17 & 5 & $\begin{array}{l}\text { gardening limited to } \\
\text { flowerbeds }\end{array}$ \\
\hline calm & 80 & 71 & 87 & 41 & 24 & 9 & active/stimulating \\
\hline fenced, closed-off & 7 & 24 & 40 & 68 & 87 & 86 & open, accessible \\
\hline safe & 140 & 94 & 47 & 13 & 16 & 1 & unsafe \\
\hline with lot of small details & 13 & 41 & 60 & 77 & 85 & 35 & with some key accents \\
\hline with new design elements & 6 & 28 & 90 & 89 & 65 & 34 & as ethnographic as possible \\
\hline modern & 2 & 9 & 40 & 101 & 96 & 64 & traditional \\
\hline for butterflies, insects & 175 & 76 & 37 & 18 & 6 & 0 & for pest and weed control \\
\hline
\end{tabular}




\begin{tabular}{|r|r|r|r|r|r|r|l|}
\hline Character feature & $\boldsymbol{1}$ & $\mathbf{2}$ & $\mathbf{3}$ & $\mathbf{4}$ & $\mathbf{5}$ & $\mathbf{6}$ & Character feature \\
\hline birdsong & 220 & 56 & 27 & 7 & 2 & 1 & loud music in farmstead \\
\hline well-groomed lawn & 21 & 38 & 68 & 83 & 61 & 42 & natural grassland \\
\hline well-maintained, cultivated & 44 & 69 & 82 & 73 & 34 & 10 & subject to natural processes \\
\hline diverse & 133 & 79 & 56 & 30 & 13 & 3 & monotonous \\
\hline mosaic-like & 50 & 63 & 77 & 56 & 45 & 22 & solid, unfragmented \\
\hline open/transparent & 67 & 89 & 95 & 40 & 16 & 5 & impenetrable, opaque \\
\hline natural & 75 & 81 & 81 & 45 & 25 & 7 & man-made \\
\hline space for nature & 64 & 69 & 100 & 48 & 25 & 6 & man's needs over nature \\
\hline
\end{tabular}

Typical countryside farmsteads are characterised by landscape elements such as old trees (mostly oaks), older apple orchards, yards laid out in a harmonious way, a well, flowerbeds, location next to natural grassland or forest and an open view of the landscape from the yard. When asked about their ideas regarding the future development of their farmyard landscape, most landowners answered that they would like to develop their property (houses), dig a pond, build a traditional bath house (sauna), invest in access road quality or build a fence or construct additional facilities in the yard - the maintenance of biodiversity was not a priority. Different ideas are held about the proper role of the local municipality in the maintenance of rural landscapes: including road improvement, the removal of abandoned buildings (on old farms), comprehensive strategic planning and measures to motivate individuals to improve the quality of rural landscapes.

There is a consensus that many ancient ethnographic elements have disappeared at high speed in recent decades from Latvian rural farmsteads, especially those with reduced functionality (e.g. wells, outdoor toilets and cellars). There has been a massive decrease in the number of households keeping small numbers of livestock and carrying out other agricultural activities (and so there has been a disappearance of haystacks, cattle sheds, stockyards, pastures etc.). There is a greater range of building materials available; the use of bright colours sometimes creates disharmony, and the proportional volume and traditional shapes of houses are changing. In general, the landscape is becoming simplified and monotonous forms are developing due to the intensification of agricultural practices.

Associated with rural farmsteads landscapes of a "poor" quality are excessively high, non-transparent fences, scrap piles left in yards, and the architectural inconsistencies created by the presence of many small huts and sheds or inappropriate building materials. Imitation of the urban environment has reduced the advantages of rural areas. Certain tastes also add to this, such as adding to the landscape artificial garden dwarfs, plaster figures, flowerbeds in old tyres or the excessive presence of exotic plants not typical for local conditions. The quality of the landscape is affected by carelessness, the presence of overgrown yards and general lack of management.

There are two general trends evident among landowners in the 21 st century concerning the management of farmsteads. Either the boundary between human space within the yard and nature has become sharper (fences, large properties with 
maintained lawns, concrete paving) to keep the wilderness or nature out, or the border has become blurred and nature is widely integrated into the human space, benefiting from usage of various ecosystem services (see Andersson 2015). In that case, natural elements are used partly as a natural design feature.

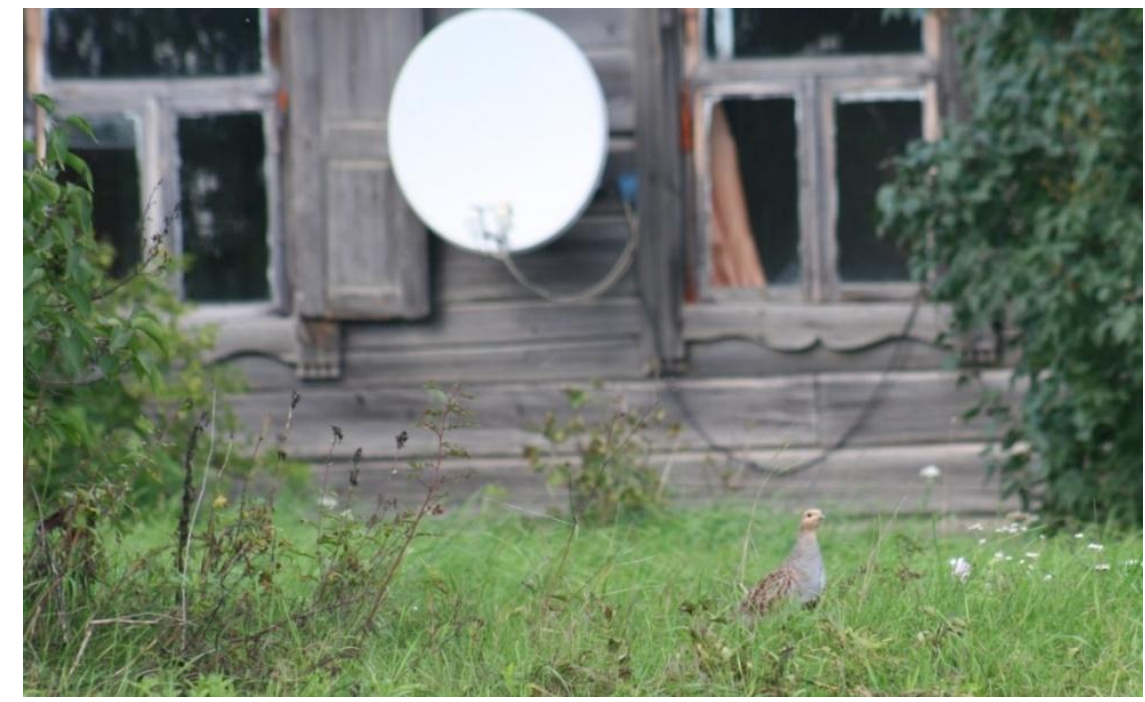

Figure 2. Grey partridge in natural grassland, next to a traditional Selonian region countryside farmstead equipped with satellite antenna in the Dviete floodplains nature park (authors' photography)

\section{Conclusion}

This research has contributed to the knowledge accumulated by other researchers about the transformation of the structure of the Latvian rural landscape and the impact of economic, social and political factors (e.g. Bunkše, Melluma, Nikodemus, Bell, Penēze, Zariņa, Aistara, Dzenovska, Ruskule, Vinogradovs and others). A comparative analysis of representations and perceptions over the course of a century prove that certain stereotypical perceptions about symbolic landscapes and idealised elements of rural landscape characteristics were reproduced by the rural community in a very similar way to how they were represented in the media before the Second World War. Certain representations of symbolic rural landscapes in the media after the emergence of the new Latvian state were chosen for political reasons, due to the fact that the majority of the electorate were living in the countryside. Certain ideas about ideal elements of rural landscapes were cultivated by the media. To achieve this, best benchmarks were used, as well as shaming those who were considered bad landlords.

The results of this research confirmed the findings of Bunkše (1999) about the importance of the rural landscape and particularly its symbolism, including the iconic image of separate family farmsteads in the continuous metanarrative of national identity during the post-Soviet, postmodern era. However, in the past, iconic images of separate family farmsteads with clusters of architectonically distinct buildings (e.g., 
the main house, byres, a stable, a large threshing barn, small granaries, a sauna) have always included the owners' never-ending working and activities in the courtyard and in the surrounding fields, adjacent forests etc., which have changed quite drastically over time. Many of these rural landscape elements have been preserved but their future preservation is in doubt as this has partially been done artificially, and there are no real functions remaining for these elements. Changes of land use in rural areas have been so intense that they have affected most of the main landscape components: forests, mires, semi-natural grasslands, river meanders and places of settlement. Farmsteads have, so far, been one of the elements in this holistic system which have been more resistant to change, because they were permanently inhabited by people who regularly carried out routine rural activities (mowing grass, harvesting, growing flowers and apple trees, pasturing cattle etc.). However, despite the existence of daily routines and a succession of generations living in the same place, continuous and gradual changes to Latvian rural farmsteads can be traced. Some landscape elements are more resistant to change (geographical formations, old trees, driveways, apple orchards), others are disappearing (including a number of smaller-scale architectural ethnographic elements that are in poor condition, no longer function or are sometimes associated with regression rather than a postmodern lifestyle, such as wells and woodpiles). Several new elements of the landscape that serve the needs of its inhabitants can be found (leisure elements and outdoor entertainment spaces, exotic plants, garden or yard decor, lighting elements, etc.). There has been further polarisation of daily routines that shape the landscape from the social side: elements used for relaxation purposes and the use of ecosystem services is dominant in cases where households aren't dependent on local resources. Although more frequent mobility is involved, more productive use of agricultural lands and larger monotonous forms are developing. In cases where households are dependent on local resources, different intermediate forms still co-exist (such as having a small garden or monthly income coming partially from doing a job in the nearest town, etc.). This partly depends on the location of the farmstead - how far it is from a town and how the physical geographical conditions there correspond to the likelihood of agriculture or forest management being the main source of income for households. Other social factors are also important - e.g. lifestyles, amount of time spent on farmstead (e.g. the number of seasonal second homes are increasing) etc. Environmental conditions, landscape harmony and biodiversity create important advantages in terms of quality of life for the countryside when compared to urban areas, and these are encouraging farmstead residents to think about nature conservation.

\section{Kopsavilkums}

Tradicionālā Latvijas lauku viensētu ainava pēdējo simts gadu laikā krasi mainījusies. Jaunsaimniecību skaits, kas izveidojās pēc 20.gs sākuma agrārās reformas, ir teju puse no mūsdienās apdzīvotajām lauku viensētām ( 12\% apdzīvotības). Vienlaikus ir vairāk nekā 29,5 tūkstoši pamestu viensētu. Agrārajai politikai valsts pirmsākumos un valdošajiem ideāliem bija liela ietekme gan praktiskajā, gan estētiskajā lauku dzīvesveida un ainavas veidošanā. Lauksaimniecība bija galvenais 
viensētu iedzīvotāju iztikas avots ar lielu iesaistīto cilvēku skaitu. Zemais darba ražīgums radīja pakāpenisku ietekmi uz cilvēka un dabas mijiedarbībā veidotajām dzīvotnēm, ḷaujot daudzām sugām pielāgoties šiem īpašajiem apstākḷiem. Tomēr mūsdienu vajadzības, dz̄ivesstils un mobilitāte, ienākumu avotu dažādošanās un tehnologiiskās iespējas turpina mainīt lauku viensētu ainavu. Izzūd pašuzturošai saimniecībai raksturīgie funkcionālie un etnogrāfiskie elementi, tiek vienkāršota tradicionālā pagalma struktūra, mainās skatu perspektīvas, reǵionos ar intensīvu lauksaimniecību ainava kḷūst monotonāka un tiek ieviesti jauni ainavas elementi. Izzūd dabas daudzveidību veicinošo elementu klātbūtne, jo nav praktiskas sasaistes ar mūsdienu dzīvesveidu, trūkst arī zināšanu. 21. gs. Latvijas lauku viensētas vērtību ietekmē pretstatījums pilsētvidei: saskanīga ainava kā nozīmīga dzīves kvalitātes sastāvdaļa, kurā cilvēka dzīves telpa un daba ir vairāk integrēta. Nacionālās identitātes vērtības līdzās dabas daudzveidības klātbūtnei un ekosistēmas pakalpojumu pieejamība palielina lauku viensētas kā konkurētspējīgas dzīves vietas priekšrocības.

\section{Acknowledgements}

The authors express their gratitude to the tourism students from Vidzeme University of Applied Sciences involved in visiting and interviewing the farmstead owners, and the Latvian Fund for Nature for the cooperation during the research. The publication was written within the framework of the post-doctoral research project No. 1.1.1.2/VIAA/1/16/100.

\section{References}

Aistara, G.A. (2009). Maps from space: Latvian organic farmers negotiate their place in the European Union. Sociologia Ruralis, 49 (2), 132-150.

Andersson, E., Nykvist, B., Malinga, R., Jaramillo, F. and Lindborg, R. (2015). A social-ecological analysis of ecosystem services in two different farming systems. AMBIO, 44, 102-112.

Antrop, M. (2005). Why landscapes of the past are important for the future. Landscape and Urban Planning, 70, 21-34.

Bell, P. (2001). Content analysis of visual images. In: Van Leeuwen, T. and Jewitt, C. (eds.) Handbook of Visual Analysis. London: Sage, 10-34.

Bell, S., Montarzino, A., Aspinall, P., Penēze, Z., and Nikodemus, O. (2009). Rural society, social inclusion and landscape change in Central and Eastern Europe: a case study of Latvia. Sociologia Ruralis, 49 (3), 295-326.

Bunkše, E.V. (1999). Reality of rural landscape symbolism in the formation of a post-Soviet, postmodern Latvian identity. Norsk Geografisk Tidsskrift-Norwegian Journal of Geography, 53 (2/3), 121-138.

Bunkše, E.V. (1978). Commoner attitudes toward landscape and nature. Annals of the Association of American Geographers, 68 (4), 551-566.

Cosgrove, D. (2006). Landscape, culture and modernity. In: Gebhardt, H. and Meusburger, P. (eds.), Geographical Imagination and the Authority of Images. München: Franz Steiner Verlag, 29-55.

Daniels, G.D. and Kirkpatrick, J.B. (2006). Does variation in garden characteristics influence the conservation of birds in sub-urbia? Biological Conservation, 133, 326-335.

Dernoi, L. (1983). Farm tourism in Europe. Tourism Management, 4 (3), 155-166.

Dzenovska, D. and Aistara, G.A. (2014). Practices and politics of rural living in Latvia: An interdisciplinary view. Journal of Baltic Studies, 45 (1), 1-16.

Gössling, S. and Mattsson, S. (2002). Farm Tourism in Sweden: Structure, Growth and Characteristics. Scandinavian Journal of Hospitality and Tourism, 2 (1), 17-30.

Henle, K., Alard, D., Clitherow, J., Cobb, P., Firbank, L., Kull, T., McCracken, D., Moritz, R.F.A., Niemelä, J., Rebane, M., Wascher, D., Watt, A. and Young, J. (2008). Identifying and managing the 
conflicts between agriculture and biodiversity conservation in Europe - A review. Agriculture, Ecosystems \& Environment, 124 (1/2), 60-71.

Hirsch, E. (1995). Introduction. Landscape: Between Place and Space. In: Hirsch, E. and O'Hanlon, M. (eds.). The Anthropology of Landscape: Perspectives on Place and Space. Oxford: Clarendon Press. $1-20$.

Hirona, M., Berg, Å., Eggers, S., and Pärta, T. (2013). Are farmsteads over-looked biodiversity hotspots in intensive agricultural ecosystems? Biological Conservation, 159, 332-342.

Latvijas Kultūras kanons. Latviešu viensēta, 16.-21. gadsimts. https://kulturaskanons.lv/archive/latviesu-vienseta/ (16.12.2019).

Lipša, I. (2011). Latvju lauki. Idilles izrakumi. Rīgas Laiks, 4. https://www.rigaslaiks.lv/zurnals/latvju-lauki-idilles-izrakumi-1035 (16.12.2019).

Melluma, A. (2012). Historical contexts and development paths of Latvian landscapes. Proceedings of the Latvian Academy of Sciences. A: Humanities and Social Sciences, Proceedings in the $24^{\text {th }}$ session of PECSRL: Living in landscapes: knowledge, practice, imagination, 66 (3), 27-41.

Nikodemus, O., Bell, S., Grīne, I. and Liepiňš, I. (2005). The impact of economic, social and political factors on the landscape structure of the Vidzeme Uplands in Latvia. Landscape and Urban Planning, 70 (1/2), 57-67.

Nikodemus, O., Bell, S., Penēze, Z. and Krūze, I. (2010). The influence of European Union single area payments and less favoured area payments on the Latvian landscape. European Countryside, 2 (1), 25-41.

Metcalfe, A.S. (2016). Repeat Photography and Educational Research. In: Moss, J. and Pini, B. (eds.) Visual research methods in Educational Research, New York: Palgrave Macmillan, 153-171.

Olwig, K.R. (2005). Representation and alienation in the political land-scape. Cultural Geographies, 12 (1), 19-40.

Ozola, S. (2015). Evolution of Architectonic Spatial Environment in Latvian Rural Populated Areas Due to Natural and Human Interaction. Procedia Engineering, 118, 251-259.

Penēze, Z. (2009). Latvijas lauku ainavas izmaiņas 20. un 21. gadsimtā: cēloṇi, procesi un tendences. Promocijas darbs. Rīga: Latvijas Universitāte, 41.

Rose, G. (2016). Visual Methodologies: An Introduction to Researching with Visual Materials. London: Sage Publication Ltd.

Rosin, Z., $\quad$ Skórka, P., $\quad$ Pärt, T., Żmihorski, M., $\quad$ Ekner-Grzyb, A., $\quad$ Kwieciński, Z. and Tryjanowski, P. (2016). Villages and their old farmsteads are hot spots of bird diversity in agricultural landscapes. Journal of Applied Ecology, 53 (5), 1363-1372.

Ruskule, A. (2013). Lauksaimniecības zemju aizaugšanas ainavu ekoloğiskie un sociālie aspekti. Promocijas darbs. Rīga: Latvijas Universitāte, 53.

Ruskule, A., Nikodemus, O., Kasparinskis, R., Bell, S. and Urtane, I. (2013). The perception of abandoned farmland by local people and experts: Landscape value and perspectives on future land use. Landscape and Urban Planning, 115, 49-61.

Sevenant, M. and Antrop, M. (2009). Cognitive attributes and aesthetic preferences in assessment and differentiation of landscapes. Journal of Environmental Management, 90, 2889-2899.

Sharpley, R., and Vass, A. (2006). Tourism, farming and diversification: An attitudinal study. Tourism Management, 27, 1040-1052.

Smith, T. (2007). Repeat Photography as a Method in Visual Anthropology, Visual Anthropology, $20(2 / 3), 179-200$.

Tribot, A.S., Deter, J. and Mouquet, N. (2018). Integrating the aesthetic value of landscapes and biological diversity. Proceedings of the Royal Society B, 285 (1886).

Vanwambeke, S.O., Meyfroidt, P. and Nikodemus, O. (2012). From USSR to EU: 20 years of rural landscape changes in Vidzeme, Latvia. Landscape and Urban Planning, 105 (3), 241-249. 
Vinogradovs, I., Nikodemus, O., Elferts, D. and Brūmelis, G. (2018). Assessment of site-specific drivers of farmland abandonment in mosaic-type landscapes: A case study in Vidzeme, Latvia. Agriculture, Ecosystems \& Environment, 253, 113-121.

Vugule, K. (2013). The Latvian landscape as seen from the road. Research for Rural Development, 2, 120-127.

Vugule, K. and Turlaja, R. (2016). Scenic roads in Latvia. Research for Rural Development, 1, 182188.

Walford, N. (2001). Patterns of development in tourist accommodation enterprises on farms in England and Wales. Applied Geography, 21 (4), 331-345.

Xu, J., Lebel, L., and Sturgeon, J. (2009). Functional links between biodiversity, livelihoods, and culture in a Hani Swidden landscape in southwest China. Ecology and Society 14 (2), 20.

Zariņa, A. (2010). Path dependency and landscape biographies in Latgale, Latvia: a comparative analysis. European Countryside, 2 (3), 151-168.

Zigmunde, D. (2010). Preservation of Traditional Rural Landscape Identity as an Integrative Tool for New Housing Settlements in Latvia. International scientific conference proceedings of full papers - Landscape Legacy: Landscape Architecture and Planning between Art and Science. 